\title{
Medicolegal
}

\section{Legality of consent to nontherapeutic medical research on infants and young children*}

\section{GERALD DWORKIN}

From the Faculty of Law, University of Southampton
Can a parent lawfully consent to nontherapeutic experimental procedures being performed on his child when that child is legally incompetent to decide for himself ?

\section{A strict legal view-and its implications}

For some years the view of lawyers advising the medical profession has been that such clinical research is unlawful. This is a view expressed, for example, by Speller, ${ }^{2}$ the Medical Research Council, ${ }^{3}$ the Medical Protection Society, ${ }^{4}$ the Medical Defence Union, ${ }^{5}$ Sir Harvey Druitt (a former Treasury Solicitor), ${ }^{6}$ Sir George Godber (a former Chief Medical Officer to the Department of Health and Social Security (DHSS)) ${ }^{7}$ and to the DHSS itself. The authority for this view rests on general legal principle rather than on any specific rule or ruling. Thus, the general philosophy of the law is that parents are under a duty to look after a child's interests and so any nontherapeutic procedures cannot be justified. A dictum from the Supreme Court of the United States, admittedly in a different context, expresses this view:

'Parents may be free to become martyrs themselves. But it does not follow [that] they are free, in identical circumstances, to make martyrs of their children before they have reached the age of full and legal discretion when they can make that choice for themselves'. ${ }^{8}$

Additional support might also be gleaned, perhaps, from the recent decision where a court refused to allow the sterilisation of a mentally retarded 11year-old girl, even though the mother and the surgeon were anxious for this to be done. Heilbron J. stated:

*This article is based on part of a lecture, 'Legal aspects of medical experimentation', given on 26 May 1977 at the Institute of Advanced Legal Studies.
'The type of operation proposed is one which involves the deprivation of a basic human right, namely, the right of a woman to reproduce, and, therefore, it would be, if performed on a woman for nontherapeutic reasons and without her consent, a violation of such right ... [This] operation is neither medically indicated nor necessary, and .... it would not be in [the child's] best interests for it to be performed'.?

What are the implications of holding this strict view of the law? Logically it should follow that there should be a total ban on nontherapeutic clinical research on children, certainly below the age of understanding. Instead, the medical authorities appear to fudge the issue by giving unclear guidance but expecting research work to continue. Thus, the Royal College of Physicians stated in 1973:

'Clinical research investigation of children ... . which is not of direct benefit to the patient should be conducted, but only when the procedures entail negligible risk or discomfort and subject to the provisions of any common and statute law prevailing at the time' ${ }^{10}$

This, of course, begs the question. A DHSS circular in 1975 commented on this statement as follows:

'Health authorities are advised that they ought not to infer from this recommendation that the fact that consent has been given by the parent or guardian and that the risk involved is considered negligible will be sufficient to bring such clinical research investigation within the law as it stands'.11

Once again, there is a reluctance to state expressly the logical implication that clinical research of this nature cannot be condoned in law. 
Many researchers, dissatisfied with this legal situation, are prepared to ignore 'the law' and take the consequences. This is a dangerous and undesirable attitude to foster towards the law. The strict view of the law may well be enforced if, as has happened, bodies funding research, such as the Medical Research Council, feel unable to grant money for such clinical research because of the problems of legality. ${ }^{4}$ A similar dilemma must face ethical research committees. No clinical research involving young children can be supported, if unlawful. It can rarely be ethical to support an unlawful medical activity. Indeed, any approval of unlawful research would expose all members of an ethical committee, as well as the researchers, to the possibility of criminal and civil proceedings!

\section{A less strict view of the law}

As the law has not yet been settled authoritatively, there is a strong case for questioning an absolutist approach. Ethical codes do not go so far. ${ }^{12}$ Indeed, it would be socially undesirable - although this is not necessarily a good argument in itself-to have a complete ban on such research.

A great American lawyer, Oliver Wendell Holmes, emphasised that the law was really a prediction of what courts will decide: 'What constitutes the law? ... The prophecies of what the courts will do in fact, and nothing more pretentious, are what I mean by the law' ${ }^{13}$ How, then, can we predict what English courts will decide? The usual techniques are, first, to examine such English law that has been decided, for what value it is; secondly, to draw analogies with other relevant areas of established English law; thirdly, if necessary, to look at the relevant laws of other countries with comparable social and legal philosophies; and finally it is submitted that in medicolegal matters a presumption should be accepted that the courts will, as far as possible, take into account ethical practices in determining the law:

'Judges are sensitive to the ethos of the times. Our society places a high premium on scientific experimentation and the pursuit of knowledge. To a greater extent than was formerly true, judges will be conscious of the conflict of interests and will seek to give due weight to each of them in any case involving experimentation carried on pursuant to current standards of propriety ... We should proceed on the hypothesis ... that in framing our ethical principles the common law will be hospitable to procedures that recognise the social value of human experimentation without sacrificing the interests of patients and subjects'. ${ }^{14}$
Various arguments for a less strict view of the law could be explored.

The central issue which the courts must examine is the scope of the powers of a parent, a guardian, a local authority, or of a court acting in loco parentis towards a child. Once again, parental duties are not clear cut! Ormrod J. recently admitted that, 'if one were asked to define what are the rights of a parent à propos his child, I for one would find it very difficult'. ${ }^{15}$

In recent years there has been a considerable amount of legislation relating to matters such as the adoption, custody, and care of children. Much of the legislation has tended to increase the emphasis on the welfare of the child. Although some provisions state that the needs of the child are paramount, other provisions refer to the welfare of the child being the first consideration. First consideration, of course, suggests that there may be other considerations, and it is possible that some of these other considerations can be balanced by a parent against the first consideration of the child, and indeed over-ride it.

The balancing of various interests can best be seen in cases where a child has been made a ward of court, and the court has to act as a judicial reasonable parent. There are several recent examples of the balancing process in operation. The sterilisation case mentioned earlier is authority for saying that a parent could not authorise anything that was not in the child's best interests. However, Heilbron J. also stated that 'the judge must act, as far as humanly possible, ... as a wise parent would act'... . A wise parent may well refuse to agree to the nontherapeutic sterilisation of his 11-year-old daughter, but might well be prepared to agree to lesser forms of nontherapeutic procedures. Another recent balancing act pitted the interests of a child against the general interest of free speech and free publication. There, the defendants proposed to publish a book describing the depraved behaviour of the deceased father of a 14-year-old girl. It was accepted that if she were to read the book or hear about it from others, it would be psychologically grossly damaging to her. The Court of Appeal, in exercising its wardship jurisdiction, was not prepared to allow the interests of the child to prevail over the wider interests of freedom of publication:

'[It is not correct to say] that in every case where a minor's interests are involved, those interests are always paramount and must prevail. ... [The court] is required to do a difficult balancing act. ... I think the scale is tipped heavily in favour of [publication] and against the [minor]. ${ }^{16}$ 
Perhaps the most relevant analogy, however, concerns the power to take blood tests from children in determining paternity. Here, the conflict is between the interests of the child and of doing justice. In 1970 the House of Lords considered a case where the Official Solicitor had appointed a guardian ad litem for a child, who had objected to a blood test on the ground that it had not been shown that it would be for the benefit of the child. This was not accepted as a sufficient argument by the court, and statements abound in the judgments that the benefit of the child is not an adequate criterion. Lengthy, but important, passages from Lord Reid's judgment demonstrate this:

'There is no doubt that a person of full age and capacity cannot be ordered to undergo a blood test against his will. ... The ... reason is that English law goes to great lengths to protect a person of full age and capacity from interference with his personal liberty. We have too often seen freedom disappear in other countries not only by coups d'état but by gradual erosion; and often it is the first step that counts. So it would be unwise to make even minor concessions....

'But the position is very different with regard to young children. It is a legal wrong to use constraint on an adult beyond what is authorised by statute or ancient common law powers connected with crime and the like.

'But it is not and could not be a legal wrong for a parent or person authorised by him to use constraint to his young child provided it is not cruel or excessive ... [it] seems to me to be impossible to deny that a parent can lawfully require that his young child should submit to a blood test. And if the parent can require that, why not the court?

'[Surely] a reasonable parent would have some regard to the general public interest and would not refuse a blood test unless he thought that would clearly be against the interests of the child?

'I would hold that the court ought to permit a blood test of a young child to be taken unless satisfied that it would be against the child's interest.'

Where do these legal analogies lead us? There seems to be clear authority for saying that a parent is not under an obligation only to act in the best interests of the child, but rather that he should not do anything clearly against the interests of the child. In other words, a parent is under an obligation to act reasonably in connection with his child. In acting reasonably a parent is sometimes entitled to weigh up various interests involved against the child's interests and may allow a child to run various risks. Thus, a parent is not acting unlawfully if he allows his child to ride a bicycle to school, though the risk of injury may be far greater than anything involved in properly conducted clinical research. A parent is not acting unlawfully in allowing his child to take part in school boxing matches. Indeed a court, when charged with deciding whether an infant professional boxer was bound by the terms of a contract, held that he was as it was of financial benefit to him, quite disregarding any question of the potential harm to which he could be subjected in the ring. ${ }^{18}$

Can it be said then that a reasonable parent might think that there was merit in balancing the social interest in contributing to medical research against the risk of injury to his child, if such risk is minimal?

The risk is clearly an important factor. Some ethical committees grade the degrees of risk involved in experimental programmes. The Medical School of the University of California has four categories: (i) no risk; (ii) minimal risk; (iii) significant risk; and (iv) major risk. Presumably, while no reasonable parent could consent to activities involving significant or major risks, since they clearly would be against the best interests of the child, it would not be unreasonable to consent to no risk or minimal risk procedures. Thus, this legal interpretation would be more realistic than the generally accepted view, and would tie in more closely with carefully constructed ethical codes.

How likely, though, is it that the courts would adopt this approach? We have looked at the relevant legal support for this view. Also, more legal writers are arguing on these lines. ${ }^{19}$ What is now required is for more positive legal advice by those influencing the medical profession. The more people who put forward this view, essentially a change of emphasis, the greater the chance of it being accepted as a valid interpretation of the law.

\section{Conclusions}

It is submitted that it is quite proper for those medical bodies which give guidance to the profession to change their present uncertain statements as to the law and replace them with a much clearer guide to the effect that 'although there is as yet no clear legal authority, it appears that it is lawful to conduct nontherapeutic research procedures on infants and young children provided the following requirements are strictly observed:

(a) the design, details, and ethical criteria of the research are approved by the appropriate ethical committee;

(b) there is voluntary, informed, parental consent; and

(c) there is no, or a minimal, risk'. 
There are many ethical and legal problems still to be resolved in connection with medical research; for example, 'informed' consent is another story. More co-operation between the medical and legal profession is required to work towards harmonious ethical and legal codes. However, this article, it is hoped, demonstrates that one of the major contentious issues is capable of a better solution than the present apparent conflict between law and practice.

\section{References}

${ }^{1}$ The literature on this matter is increasing. For recent important articles see: Archives of Disease in Childhood (1973). The ethics of research involving children as controls. (Editorial), 48, 751-752;

Skegg, P. D. G. (1973). Consent to medical procedures on minors. Modern Law Review, 36, 370-381;

Campbell, A. G. M. (1974). Infants, children and informed consent. British Medical Journal, 3, 334-338;

Dickens, B. M. (1975). The use of children in medical experimentation. Medico-Legal Journal, 43, 166-172;

Skegg, P. D. G. (1977). English law relating to experimentation on children. Lancet, 2, 754-755;

Cross, K. W. (1977). Experimentation on children. Lancet, 2, 866;

Soothill, J. F. (1977). Research on infants. Lancet, 2, 1278-1279.

${ }^{2}$ Speller, S. R. (1971). Law Relating to Hospitals and Kindred Institutions, 5th ed., pp. 144-145. H. K. Lewis, London.

${ }^{3}$ Medical Research Council (1964). Responsibility in investigations on human subjects. British Medical Journal, 2, 178-180.

${ }^{4}$ Leahy Taylor, J. (1975). Ethical and legal aspects of nontherapeutic clinical investigation. Medico-Legal Journal, 43, 53-68.

${ }^{5}$ Pratt, H. (1977). Research on infants. Lancet, 1, 699; 1052.
${ }^{6}$ Curran, W. J., and Beecher, H. K. (1969). Experimentation in children; a reexamination of legal ethical principles. Journal of the American Medical Association, 210, 77-83.

${ }^{7}$ Godber, G. (1974). Discussion. Symposium on Constraints on the Advance of Medicine. Proceedings of the Royal Society of Medicine, 67, 1311.

${ }^{8}$ Prince v. Massachusetts (1944). United States Supreme Court Reports, 321, 158.

${ }^{9} \operatorname{Re}$ D. (A Minor) (Wardship: Sterilisation) (1976). Law Reports, Family Division, 185 at 193, Heilbron, J.

${ }^{10}$ Royal College of Physicians of London (1973). Committee on Supervision of the Ethics of Clinical Research Investigations in Institutions. The College, London.

${ }^{11}$ Department of Health and Social Security (1975). Supervision of the Ethics of Clinical Research Investigation and Fetal Research.

${ }^{12}$ Ingelfinger, F. J. (1977). Ethics of human experimentation defined by a National Commission. New England Journal of Medicine, 296, 44-45.

${ }^{13}$ Holmes, O. W., Jr. (1897). The path of the law. Harvard Law Review, 10, 457-478.

${ }^{14} \mathrm{Jaffe}$, L. L. (1972). Law as a system of control. Experimentation with Human Subjects, p. 207. Ed. by P. A. Freund. Allen and Unwin, London.

${ }_{15} \operatorname{Re~N.~(A~Minor)~(Minors)~(Parental~rights).~(1974).~All~}$ England Law Reports, 1, 126-131.

${ }^{16} \operatorname{Re} X$. (A Minor) (1975). All England Law Reports, 1, 697 at 706, Roskill, L.J.

${ }^{17} S$. v. S. (1970). All England Law Reports, 3, 107 at 111-112, Reid, L.J. This law is now confirmed by statute: Family Law Reform Act, 1969, s. 21.

${ }^{18}$ Doyle v. White City Stadium Limited (1935). King's Bench Division, 1, 110-139.

${ }^{10}$ e.g. see Skegg, Dickens, ref. 1. above.

Correspondence to Professor Gerald Dworkin, Faculty of Law, The University, Southampton SO9 $5 \mathrm{NH}$. 